\title{
Ecological Law of Russia: Milestones of Formation
}

\author{
Boris Zemtsov \\ Bauman Moscow State Technical University \\ 5/1 2d Baumanskaya Street \\ Moscow, Russia 105005 \\ E-mail: zemtsovbn@mail.ru
}

\author{
Tatyana Suzdaleva \\ Bauman Moscow State Technical University \\ 5/1 2d Baumanskaya Street, \\ Moscow, Russia 105005 \\ E-mail: syzdalev@list.ru
}

\begin{abstract}
The article is devoted to the determination of the period of the formation of environmental law. The solution of this problem provides an opportunity for a deeper understanding of the essence of this branch of law by those who deal with it today. According to the authors, the basis for asserting that this occurred at one time or another should be the existence of a subject and principles that correspond to the subject and principles of modern environmental law. B.N.Zemtsov and T.R.Suzdaleva believe that it was formed not earlier than the 1960s, when the contours of the solution of the primary material and household problems of the Soviet people were identified and the question of the quality of life arose.
\end{abstract}

Keywords-environmental law; environmental protection; environmental legislation

\section{INTRODUCTION}

Environmental law is a system of legal norms regulating social relations in the sphere of interaction between society and nature [1].

There are different views on the period of the formation of environmental law. The basis for them is the emergence of normative legal acts regulating the attitude to the objects of flora and fauna. According to the authors, the basis for the claim that this right has arisen at one time or another, should be the presence of the subject and the principles corresponding to the subject and to the principles of modern environmental law.

\section{LEGISLATION OF YAROSLAV THE WISE}

M.B.Bulgakov and A.A.Yalbulganov [2], E.V.Kail [3] sees the origins of environmental law in the "Russian truth". Argument for this are the articles that established the penalty for theft of firewood, for destruction of or damage to bumpers, theft of the beaver [4]. This argument seems, at the very least, controversial. Experts on the history of old Russian law referred the norms of "Russian truth" to the sphere of civil, criminal and criminal-procedure law, but never to environmental law [5]. The coincidence of the subject of future environmental and civil law is nothing more than an accident.

The lack of hints on the prerequisites for environmental law in Ancient Russia can be easily found in the analysis of the legal principles of the "Russian truth". Modern principles of environmental law include: legal support of harmonious interaction between society and nature; legal support of environmental safety; priority of protection of the use of natural objects, etc. It is clear that during the reign of Yaroslav the Wise these principles were irrelevant.

\section{LAW IN THE XVII CENTURY}

Some acts of ecological orientation appeared in the XVII century.:

- decree of 1635 "On the prohibition of catching beavers and otters with traps»;

- decree on the procedure of catching fish in Plesheevo lake of 1676 instructed to catch only a big herring. For catching small herring " warden and fishers must have death penalty»;

the decree of 1640 in Moscow prescribed that "...dead horses, and every animal outside the city on bare ground must be put deep in the ground not shallow ....and in the streets and in the countryside, in villages the dead horses and every dead cattle, and dead dogs, and cats ...nothing dead.. can be nowhere left in the open...».

It is unlikely that the argument in favor of the emergence of environmental law at that time can be considered the statement that it developed within the framework of civil law [6]. And in the XVII and XVIII centuries the legal regulations pursued different goals than modern environmental law. For example, the protection of forests was aimed at protecting an important source of government revenue - sable. In the decree of 1681 it is clearly stated: «yasak (hunting) areas of forests are not cut and not burned and the beast would not run far away ... and there should not be made destruction or evil to the collection of yasak (natural $\operatorname{tax})$ [7].

\section{THE LEgISLATION OF PETER I}

It is much more logical to attribute the emergence of the foundations of environmental law to the reign of Peter I:

- in 1696 at the initiative of Peter 1organized afforestation began ;

- in 1701 there appeared a decree "On prohibition to cut forests along the rivers, by which the timber is floated to Moscow, and to clean them 30 miles up»; 
- in 1703 - the law on protected forests. Forests along the rivers were declared protected: for large rivers the width of the forbidden zone was 50 versts, for small rivers -20 versts;

in 1704 Peter I by the decree forbade destructive ways of production of fish (pins, hooks without bait, nets, without special permission).

In total, more than 60 decrees regulating the use of natural resources were adopted in his reign. This meant that environmental policy-making had begun. However, there existed no ideas about the relationship of man and nature in his reign. And then they talked not so much about nature protection, but, first, about the protection of property rights to natural resources, and secondly, the problem of environmental protection from pollution was treated to be a sanitary, not an ecological one.

\section{ENVIRONMENTAL LEGISLATION AT THE END OF XIX - BEGINNING OF XX CENTURY}

O.S.Kolbasov [8], O.L.Dubovik [9], V.V.Petrov [10], Y.S.Shemshuchenko [11] the emergence of environmental rights refer to the last third of the XIX century. The reason for this is the uprise of modern ecological principles. For example, the" Mountain Charter" of 1893 provided for state intervention in the rights of a private owner, the prohibition of uncontrolled use of forests, the right of the state to expropriate forests from those forest owners who violate the law. But, most likely, we can talk about the formation of environmental principles at that time. There was no need for the developed environmental law at that time:

Firstly, the population density in Russia was insignificant, the country's natural resources seemed limitless, and the dangers of pollution, in fact, did not exist;

Secondly, natural resources were a source of public and private income, the significance of which almost eliminated the concern about the decline in these resources.

\section{ENVIRONMENTAL LEGISLATION OF THE USSR}

In the educational and methodical literature the statement that the Soviet legislator addressed environmental problems already in the first years of the Soviet power is widespread. As justification of the views their supporters refer to the decree of 1917 "On the land", the decree "On the forests» of 1918, in the 1920s were adopted: the decree of the Council of People's Commissars of RSFSR of April 30, 1920 "On the interior of the Earth"[12], the decree of the Council of People's Commissars of RSFSR of July 20, 1920 "On hunting " [13], the Forest code of 1923 [14], etc. However, for example, the decree of 1917 "On land" and the decree "On forests" of 1918 belong to the sphere of constitutional law. The content of the first decree was the development of the political activity of the peasants through transferring the land into their hands. The content of the second decree is the declaration of land as state property.

At first glance, it is logical to see the origins of environmental law in the decree "On hunting" (1920), since paragraph 3 contained a provision on the "establishment of sanctuaries, wildlife reserves, zoological farms, laboratories, hunting parks and nurseries of fur-bearing animals, birds and hunting dogs" [15]. But further development of this sphere of legal relations (decree of the All-Union Central Executive Committee and of the Council of People's Commissars of RSFSR of August 24, 1922 "Rules of carrying out hunting, its terms and methods", the resolution of the Council of People's Commissars of RSFSR of September 3, 1931 "About actions for streamlining hunting industry") says that the legislator, first of all, cared about the protection of wild birds and animals as the state hunting Fund, which brought to the state a big income [16].

In the 1930s industrialization replaced environmental problems from the government's attention, and in 1945-1950 there was the task of reconstruction and accelerated development of the national economy [17].

\section{ENVIRONMENTAL LAW}

The conducted research allows to consider the 1960s as the time of shaping the Soviet ecological law. By this time the contours of the solution of the primary material and everyday problems of the Soviet people were outlined and the question of the quality of life arose [18].

In 1960 the first consolidated law of the RSFSR "On Nature Protection in the RSFSR" was adopted. Its value can not be overestimated:

- it set out important principles, norms and limitations,

- the law almost drew a line under "natural resources" stage for the conservation of nature and the use of natural resources [19=18],

- after its adoption, intensive work at the national levels began.

With the adoption in 1968 of the Foundations of land, water, forest and mining legislation of the USSR and the Union republics water, forest and mining law began to develop as independent branches. The RSFSR adopted such acts as the Land code of the RSFSR (1970), the Water code of the RSFSR (1972), the Code of the RSFSR on mineral resources (1976), the Forest code of the RSFSR (1978), the Law of the RSFSR on the protection of atmospheric air (1982), the Law of the RSFSR on the protection and use of wildlife (1982).

In 1972, a joint resolution of the CPSU Central Committee and the USSR Council of Ministers "On strengthening the protection of nature and improving the use of natural resources" was adopted. In 1988, the CPSU Central Committee and the USSR Council of Ministers adopted a resolution "On a fundamental restructuring of the nature protection in the country."

From the point of view of the current level of development of law in general and environmental law in particular, these decisions were still imperfect. Significant gaps remained. There were powerful obstacles of a general nature to the implementation of laws. First of all, there were no economic incentives for enterprises to use natural 
resources rationally. But the legislation already arose and developed.

A new stage in the development of environmental law began in the 1990s. The changed political situation in the country required a radical revision of the current legislation.

The legal framework of this branch of law during this period significantly strengthened and expanded. There were adopted:

- on December 19, 1991 the Supreme Soviet of the RSFSR adopts the law of the RSFSR " On environmental protection»,

- Federal law No. 52-FZ of 24 April 1995 "On wildlife»,

- Federal law "On the continental shelf of the Russian Federation" of November 30, 1995,

The Federal law of May 4, 1999 "On protection of atmospheric air».

This was followed by: laws on ecological expertise, on hydro-meteorological service, on specially protected natural territories, on natural healing resources, on the continental shelf, on the exclusive economic zone of the Russian Federation, on internal sea waters, the territorial sea and the adjacent zone, a series of laws in the field of protection and use of land, laws regulating radiation safety, on the safety of hydraulic structures, on industrial safety of hazardous production facilities, on the destruction of chemical weapons, on safe handling of pesticides and agrochemicals, on production and consumption wastes, on protection of population and territories from natural and man-made emergencies, on state regulation in the field of genetic engineering [19]. All this together gives reason to believe that it was during this period that environmental law was finally formed as an independent branch of the Russian legal system.

In 2002 the "Ecological doctrine of the Russian Federation», developed and approved by the government of the Russian Federation, was adopted. It defined the goals, objectives, directions, principles and methods of implementation of the state policy in the field of ecology for the long term period [20]. This doctrine was the basis of ecological programs of development of subjects of the Russian Federation and industrial enterprises.

The first two decades of the XXI century were not only the time of expansion of the spheres of regulating environmental law, but also the clarification of the subject, which is very important for its further development. Legal scholars have proposed a new conceptual approach to environmental law. The basis is the attitude to the person as a biosocial being in two systems, natural and social [21]. This is a different perspective on the attitude to nature, which requires revision of the environmental policy of the state.

\section{CONCLUSION}

The first normative-legal acts in which mention was made of the flora and fauna objects as a subject of legal regulation appeared in the days of the "Russian truth",
However, the conducted analysis allows to conclude that out of the numerous concepts for determining the creation of environmental law the most scientifically sound is the position of those scholars who attribute the emergence of this branch of law to the 1960-s of the XX century. It was then when the object and principles of modern environmental law were shaped.

\section{REFERENCES}

[1] B.N. Zemtsov. Fundamentals of law. M.: University book, 2012. P 410 .

[2] M.B. Bulgakov, A.A.Yalbulganov. Conservation acts: from the "Russian truth" to Peter's times // State and law. 1996. No. 8. P.136.

[3] E.V. Kail. History of formation of ecological law of Russia during the reign of Peter I / / Scientific notes of Taurida national University named after V.I.Vernadsky. Series "Legal Sciences". Volume 27 (66). 2014. No. 3. P. $88-89$.

[4] Russian legislation of $\mathrm{X}-\mathrm{XX}$ centuries: in 9 volumes. Moscow: Legal literature, 1984. Vol.1. P. 62.

[5] B.N. Zemtsov. The history of the national state and law. Textbook for students of higher educational institutions, who study "Jurisprudence". M.: Yurayt, 2012. P. 49.

[6] O.R.Sarkisov, E.L.lubarsky. Environmental law. Textbook for students of institutions of higher education. Kazan, Center of innovative technologies. 2014. [Electronic resource] . - Access mode: http://kpfu.ru/portal/docs/F331996391/PRAVO.pdf. - 2.03.2018.

[7] Historical Acts, collected and published by the Archaeographic Commission: in 5 volumes. V. 5. SPb.: Type. Expeditions of storing State papers, 1842. Pp. $346-347$

[8] O.S.Kolbasov. Ecology: politics - law. Moscow: Science, 1975 [Electronic resource] - $\quad$ Access mode: http://lawlibrary.ru/izdanie2141.html. - 20.03. 2018.

[9] O.L.Dubovik. Formation of ecological policy: history, achievements, tendencies and tasks (analysis of O.S.Kolbasov's theoretical heritage) // Agrarian and land law. 2007. No. 9. [Electronic resource] . Access mode: http://lawlibrary.ru/article2055789.html. - 16.03. 2018.

[10] V.V.Petrov. Ecological law of Russia: Textbook. M.: BEK, 1995 [Electronic resource] . - Access mode: http://lawlibrary.ru/izdanie2148.html. - 06.03.2018).

[11] Y.S.Shemshuchenko. Legal problems of ecology. Kiev: Science, 1989. [Electronic resource] - - Access mode: http://lawlibrary.ru/izdanie2148.html. - 04.03.2018.

[12] Collection of legalizations and orders of the government in 1920. M.: Department of affairs of the Council of People's Commissars of the USSR. 1943. P. 245-246, 458-459.

[13] Ibid.

[14] Collection of codes of the RSFSR. Moscow: Publishing House of the People's Commissariat of justice of the RSFSR, 1925. P. 231-244.

[15] Complete collection of laws of the USSR // [Electronic resource] . Access http://www.ussrdoc.com/ussrdoc_communizm/ussr_728.htm. 01.03.2018.

[16] V.Kholostov. Law on hunting // Hunting and the hunting industry 1958. No. 3. [Electronic resource] . - Access mode: http://9cordon.ru/index.php/zoo/dopolnitelno/item/zakonopolozheniy a-ob-okhote. - 26.03.2018.

[17] B.N.Zemtsov. Establishment of the Soviet state mechanism // Bulletin of Tomsk Polytechnic University. 2014. Vol. 324. No. 6. P. 96-102.

[18] T.R.Suzdaleva. Modernization in the understanding of scientists Modernization as a condition for the development of modern Russia. XI international scientific-practical conference. Moscow: MESI, 2011 P. 42-46; T.R.Suzdaleva, K.V.Fedorov. "Reactive" model of modernization: theoretical and historiographical aspects//Humanitarian Vestnik of MGTU named after H.E. Bauman. 2013. No. 5 (7). P. 1 
[19] O.L.Dubovik. Ecological law: reality and attempts of revisionism //Proceedings of the Institute of state and law of the Russian Academy of Sciences. Actual problems of environmental law. - M.: Institute of state and law of Russian Academy of Sciences, 2010, № 2. P. 7-37.

[20] M.L.Ivleva. On the conceptual content of the ecological paradigm of public consciousness // The Year of Ecology in Russia: Pedagogy and Psychology in the Interests of Sustainable Development: a collection of articles of the Scientific and Practical Conference (December 4-5, 2017, Moscow) / Editors: M.O.Mdivani, V.I.Panov, Yu.G. Panyukova. M .: Publishing House "Pero", 2017. - 541p. - P. 250-255.

[21] M.M.Brinchuk. Environmental law: objects of ecological relations. Moscow: Institute of state and law of RAS, 2011. 152 p. 